Flaviu Ciopec, Ph.D., Associate Professor

West University of Timișoara, Romania

\title{
SIMPLIFIED, YET NOT SIMPLISTIC: DECISION- MAKING IN CRIMINAL COURTS IN ROMANIA
}

\begin{abstract}
Summary
This study aims to present some basic characteristics of the Romanian model of criminal procedure, based on the enactment of the new Code of Criminal Procedure (2014). The main features of this model are analysed, having in mind the ancient Code (1969), now repealed, in order to reveal a paradigm shift of decision-making within criminal proceedings.

There are three issues to address: plea bargain, guilty plea and nolo contendere procedure. All these procedures are new, powered by a heterodox and challenging doctrine. The first procedure adopted is the plea bargaining, the expression of a consensual justice and only apparently negotiated. In particular, during the criminal investigation stage, the defendant, after being charged, has the possibility to initiate or accept a bargain with the prosecutor, in order to admit the committed act and its legal qualification, the type and the amount of the penalty, and even the mode of its execution. Once signed, the agreement is subject to approval by a court of law, which supervises compliance with the legal conditions under which the bargain has been concluded. The defendant does not have the opportunity to negotiate, but, similarly to a pre-defined contract, only to agree or disagree with it.

Another procedure similar to the aforementioned one is the guilty plea of the defendant before a criminal court after being indicted. The two proceedings are alike in terms of their effects, involving a simplified procedure, where the role of the judge is rather formal. Like the plea bargaining, this procedure brings an important benefit to the defendant: a one-third decrease in the legal latitudes of the imprisonment penalty of the offense for which he was indicted (in the case of a fine the decrease is by a quarter). Unlike the plea bargaining, which is a bilateral agreement, the guilty plea is simply a unilateral act of the defendant.
\end{abstract}

Finally, a nolo contendere procedure has been timidly provided for, and involves that evidence collected in the investigation stage shall no further be supplied before the criminal court, after the prosecution of the defendant, if the latter does not contest it. Such a procedure, which underlies from the part of the judge a waiver of the direct examination of the evidence, overrides the importance of the criminal investigation stage as a decisive approach to evidence.

Although the said proceedings simplify the role of the judge, they sometimes run the risk of complicating decision-making in criminal trials, which thus becomes increasingly intricate.

Keywords: guilty plea, plea bargain, nolo contendere procedure, criminal proceedings 


\section{Introduction}

2019 marks the $50^{\text {th }}$ anniversary of the entry into force of the Romanian Criminal Procedure Code (1969) and 5 years since the enactment of a new Code of Criminal Procedure (2014). These two events should not be perceived as overlapping, given that the previous code is history, having been repealed on February 1, 2014. However, the "anniversary" is relevant, since 45 years after an authoritarian drift, during which the model that mattered most was the inquisitorialbased process, the Romanian law-maker felt the need to develop a new paradigm of the criminal process ${ }^{1}$ capable of facing the contemporary challenges. From this perspective, certain institutions newly introduced in the current code have led to the re-thinking of the decision-making within the criminal proceedings ${ }^{2}$.

Speaking of the inquisitorial-based approach of the ancient code, its first basic feature must be noted: the uniqueness, i.e. unique agent, unique objective, unique standard of proof. All the proceedings were dominated by a magistrate, i.e., a prosecutor and a presiding judge, acting as the main and single agent of the state, one in the investigation phase and the other in the trial. No decision could be adopted without the will of a magistrate, being the truly expression of an almighty state, master of the criminal justice. The new code does not alter this and continues to keep the power of the state unaltered. Once again, we have the same dominant agent, which multiplies its roles: a prosecutor as the chief-investigator in the pretrial stage, a judge of custody and liberty, as the decider in such sensitive matters as the liberty of the defendants, a judge of a preliminary chamber, a filter-judge for unlawfully conducted investigations and a presiding judge.

Finding the truth was the unique objective of the criminal trial. All participants to trial, including the defendant, were compelled to support this objective. No effort was spared to reach this goal. Thus, the state legitimized oneself by having a noble and important mission. In fact, the obsession for the truth devoured all the energies of the process, only to deliver mere fragments of truth.

The new model brings about the duality: no more unique objective, but two equally powerful goals. Besides finding the truth, another objective was set as trustworthy: the fair trial ${ }^{3}$. This one does not exclude the previous, but channels the energies towards the way of conducting the process. Managing the trial in a good manner will safeguard the rights of the participants and will allow a result strengthened by the idea of a methodologically cleaned truth.

1 For a detailed approach to the subject see Ciopec F. The New Romanian Code of Criminal Procedure. Journal of Eastern European Criminal Law, No. 1, 2014, pp. 33-52. For an adverse opinion "[..] we are not in the presence of a new model of criminal process" see Mateuț Gh. Procedură Penală. Partea generală [Criminal Procedure. General Part]. Bucharest: Universul Juridic, 2019, p. 61.

2 Decision-making in criminal proceedings is a topic mostly address by the Anglo-Saxon doctrine, but interesting to discuss in a civil law country as Romania. See Ashworth A. \& Redmayne M. The Criminal Process. New York: Oxford University Press, 2010, pp. 2-9.

3 Ghigheci C. Principiile procesului penal în noul Cod de procedură penală [Principles of Criminal Trial under the New Criminal Procedure Code]. Bucharest: Universul Juridic, 2014, p. 127. 
Taking a decision in a trial dominated by a magistrate was very much determined by a unique standard, known as the intimate conviction. This standard was not promoted by the national Constitutional Court in a decision aimed at limiting the margin of discretion assigned to judges ${ }^{4}$. Even if such a standard continued to exist, it certainly would not mean free conviction. Paradoxically, even though the standard had been formally abolished, it managed to survive precisely because the law did not provide for any criteria to explain how the decision-making process worked effectively. The magistrates were the agents of the state, trained to save the state's quasi-monopoly on the criminal justice. Changing the objectives of the trial means also shifting to a new position of the magistrate within the trial. An independent and impartial magistrate, even in relationship with the state, is an outcome consecrated by the European Court of Human Rights as a basic principle of a fair trial. Thus, it was needed to develop new standards of proof, as threshold for adopting a decision in a criminal trial. Dual objectives entail minimum dual standards. The main new instruments include reasonable suspicion and beyond any reasonable doubt ${ }^{5}$.

The second feature of the ancient code was that no settlement was possible (the truth was too much important). The idea of bargaining with criminal charges was totally excluded. The new code introduced three new procedures based on the opposite of such idea (plea-bargaining, guilty plea and nolo contendere procedure). The trial opened towards negotiation and party-to-party settlement, in an effort to de-monopolize the absolute powers of the state.

In brief, the decision-making process within the normative ambit of the ancient code was concentrated on facts, guilt and punishment. The model remained constant under the new code but received a supplement: validation of the settlements.

This short introduction has aimed to outline the basic features of the new model of criminal trial in Romania in order to reveal a paradigm shift of decision-making within the criminal proceedings. There are three issues to address: plea bargaining, guilty plea and nolo contendere procedure.

\section{Criminal judge facing paradigm shift}

The first adopted procedure is the plea bargaining 6 . In particular, during the criminal investigation stage, the suspect, after being charged and standing as

\footnotetext{
Art. 63 (2) of the former Criminal Procedure Code (1969) concerning the assessment of an evidence by using the intimate conviction was found unconstitutional. The judges are subject only to the law, which excludes any reference to their intimate conviction (Romanian Constitutional Court judgement No. 171 of 23 May 2001 published in Official Journal No. 387 of 16 July 2001. Available at: http://legislatie.just.ro/Public/DetaliiDocument/29602 [last viewed November 10, 2019].

5 Udroiu M. Procedură Penală. Partea generală [Criminal Procedure. General Part]. $6^{\text {th }}$ edition, Vol. I, Bucharest: C.H. Beck, 2019, pp. 418-420.

6 Criminal Procedure Code, Articles 478-488. Available at: http://www.just.ro/wp-content/ uploads/2016/01/Noul-cod-procedura-penala-EN.doc [last viewed November 10, 2019].
} 
defendant, has the possibility to initiate or accept a bargain with the prosecutor. The bargain is focused on all the elements of a criminal process, i.e. the defendant has to admit the committed act, to accept the legal qualification of the act as results from the official charges against him, to assume the type and the amount of the penalty proposed for the offence, and to agree even the mode of the penalty execution. The penalty settled is a mitigated one: a one-third decrease in the legal latitudes of the imprisonment penalty of the offense for which he was indicted (in the case of a fine the decrease is by a quarter).

There is a single prerequisite for concluding such an agreement: the legal penalty must be either a fine or imprisonment not exceeding 15 years. Offences like murder, aggravated murder, victim's death consecutive rape or victim's death consecutive robbery are excluded, due to their higher latitudes of penalty.

Plea-bargaining was applied to minor, as well as adult defendants, and could envisage not the imposing of a penalty, but also a waiver of penalty or a postponement of penalty.

Once signed, the agreement is subject to approval by a court of law, which supervises the compliance with the legal conditions, under which the bargain was concluded. The court could reject the agreement, if the solution accepted by the parties was illegal or too lenient compared to the seriousness of crime or the dangerousness of offender?

The second procedure relevant for this study is the guilty plea $^{8}$. Unlike the pleabargaining procedure, it takes place during the criminal trial stage, after the defendant was indicted and referred to trial. The bilateral feature of the plea-bargaining is not present here, because the procedure is initiated only by the defendant (adult or minor) by filing a request before the court. In particular, the defendant shall ask for a guilty plea, i.e. assume the committed act as charged, based on the evidence collected and supplied in the pre-trial stage. The court could allow the request and thus there shall be no trial. The verdict could be guilty and a mitigated punishment similar to plea bargaining could be inflicted (a 1/3 decrease in the legal latitudes of the imprisonment penalty for the indicted offense or a $1 / 4$ decrease in case of a fine). Nonetheless, the court could dismiss the request and continue the trial as an ordinary procedure. In this case, if the judge's fact-finding confirmed the confession of the defendant, the verdict could be again a mitigated one (as above). The benefit had to be granted since the confession of the defendant occurred at the very beginning.

This procedure is less formal than the plea bargaining, irrespective of the limits of fine or imprisonment, with one notable exception, i.e. life imprisonment.

Bodoroncea G. Acordul de recunoaștere a vinovăției [Plea Bargaining]. In: Codul de Procedură Penală. Comentariu pe articole [Criminal Procedure Code. Commentary on Articles]. $2^{\text {nd }}$ edition, Bucharest: C.H. Beck, 2017, pp. 1942-1943.

8 Criminal Procedure Code, Articles 374 (4), 375, 377 and 396 (10). Available at: http://www.just. ro/wp-content/uploads/2016/01/Noul-cod-procedura-penala-EN.doc [last viewed November 10, 2019]. 
The confession of the defendant refers only to the act committed. No acknowledgment of the legal qualification is required. Thus, the defendant could use the right to challenge the legal qualification of the confessed act.

Despite of the defendant's confession, the court is not legally bound to it and preserves the option to dismiss the criminal charges, if no grounds for conviction appear to exist.

Finally, the third procedure: nolo contendere ${ }^{9}$. Similarly to guilty plea, after the defendant (minor or adult) was indicted and sent to trial, the sitting judge shall ask the defendant if he intended to file a motion against the evidence-gathering during the investigation stage. In case of no challenge, no trial occurs, since no grounds exist to overturn fact-finding. The court gives the floor to the parties on the merits of the case and shall rule based on the evidence collected and supplied in the pre-trial phase ${ }^{10}$. In case of challenge, the trial shall follow the regular procedure. Despite the defendant's nolo contendere position, the court preserves the option to dismiss the criminal charges, if no consistency of evidence exists whatsoever.

This procedure is not limited by any condition, i.e. it is applicable irrespective of the penalty provided by law (fine or imprisonment), with no exceptions. The significant difference from the other procedures is that the defendant does not enjoy any benefit for contributing to an abbreviated trial.

Simplified by nature, all the aforementioned procedures are not simplistic, since they trigger a paradigm shift of the decision-making in criminal trial. This change (which could also be a challenge) gives room to some observations.

First of all, all procedures are examples of an abbreviated justice, as long as they do not involve an ordinary trial, but a simplified one. Plea-bargaining entails no trial, except a validation procedure of the agreement concluded between the prosecutor and the defendant. Plea bargaining is an example of consensual justice, only apparently negotiated, since the defendant does not have the opportunity to negotiate, however, like in a pre-defined contract, only to agree or disagree.

Guilty plea and nolo contendere procedures bring about a short trial. The difference is that plea-bargaining is a bilateral procedure which involves the prosecutor and the defendant, upon concluding the agreement. Guilty plea and nolo contendere procedures imply a unilateral approach, of the defendant only. In the first case, the defendant, being aware of the benefit provided by law (mitigated penalty), voluntarily admits the committed act. In the second case, the judge shall ask the defendant if he agrees with the evidence- collected during the investigation phase. By the defendant's decision not to contest (nolo contendere) the evidence, without making any statements as to the act committed, the defendant solely changes the course of the trial.

Criminal Procedure Code, Article 374 (7). Available at: http://www.just.ro/wp-content/ uploads/2016/01/Noul-cod-procedura-penala-EN.doc [last viewed November 10, 2019].

10 Ciopec F. Crime Control or Due Process? Which are the Tendencies in Romanian Criminal Justice. Journal of Eastern European Criminal Law, No. 1, 2017, p. 198. 
Nevertheless, an abbreviated trial is an efficient way of dealing with criminal justice. Efficiency instead of Justice? And what does efficiency mean? Several answers could be envisaged.

Efficiency could mean a fast settlement of the trial, no matter what the merit decision could be. The faster, the better. Judicial proceedings are reputably known as time consumers to that end that a late solution means no solution at all. Are the procedures described above qualified to reverse that situation? Without a doubt, managing a simplified procedure and abandoning the complex architecture of an ordinary trial are real options.

Efficiency could also mean a faster conviction of the defendant. The main goals of a repressive procedure are to control criminality by imposing criminal sanctions. All the abbreviated procedures are convergent towards this goal: the defendant accepts the conviction by signing the plea bargaining or agrees with the indictment either voluntarily (guilty plea), or tacitly (nolo contendere procedure). The result is quite the same and it looks like it was supported in Romania by judicial statistics: in more than 10 years the acquittal percentage never exceeded $2.8 \%$ of the total indictments ${ }^{11}$ and for 7 years the conviction percentage was more than $98 \%$. The biggest difference from one year to another emerged in 2013 and 2014, precisely upon enforcement of the new Criminal Procedure Code. Apparently, the new code brought about increased chances of the defendants to enjoy an acquittal decision (from $1.3 \%$ to $2.8 \%$ ). The next few years shattered this illusion.

Secondly, all the abbreviated procedures are important for decoding the new role of the judge in criminal proceedings in Romania. In the plea-bargaining procedure, the judge only censors the legality of the agreement. In the guilty plea, the judge only rules on a mitigated punishment. Finally, the nolo contendere procedure bears the risk that the direct examination of evidence is waived by the presiding judge. One issue must be emphasized here, namely, the concern about overriding the importance of the criminal investigation stage as a decisive approach to evidence. In all cases, the fact-finding dimension of the trial (performed by a judge) no longer exists, and the evidence 'lab' is totally conceded to the prosecutor.

Thirdly, a consequence arises from leaving the judge aside the trial scene. The judge is the epitome of the modern trial. He is an iron fist in a velvet glove, since he embodies the authority of commanding (imperium) in a rationale and argumentative wisdom (jurisdictio). At least in civil law countries, the judge is the last bastion of truth. Issuing a verdict on merits actually means that the judge authenticates a factual basis as the truth. By removing the judge's power to authenticate, and transferring it to the participants of the trial (prosecutor and defendant making their own truth, defendant admitting his fate unilaterally, and so on) the truth changes its morphology. We have to get used to a real shift of the notion of justice itself.

11 Romanian Superior Council of Magistracy. Reports on the State of Justice 2007-2018. Available at: https://www.csm1909.ro /267/3570/Rapoarte-privind-starea-justi\%C5\%A3iei [last viewed November 10, 2019]. Acquittal index in $2007-2.5 \%, 2008-2.6 \%, 2009-1.6 \%, 2010-1.4 \%$, $2011-1.8 \%, 2012-1.6 \%, 2013-1.3 \%, 2014-2.8 \%, 2015-2 \%, 2016-1.3 \%, 2017-1.7 \%$, $2018-2.2 \%$. 
Do all these changes preserve the fair trial principle? Since the defendant as a main character/subject of the criminal trial admits the conviction for the purpose of saving time, costs and benefitting from the minimum public exposure, no one is left to challenge the verdict. If the procedural safeguards are fulfilled, such a verdict mimetically approaches the real truth. Fair trial is not a guarantee for finding the said truth, but only that the final solution is not reached by mistake. From this point of view, better a methodically obtained error, than the sad victory, which is the truth found by chance ${ }^{12}$.

\section{Conclusions}

The present study has been conceived as an introductory survey of the criminal trial in Romania. The research has revealed that three specific procedures have recently developed as alternatives to the ordinary trial. These new procedural frameworks are much faster, simpler and less formal. It is not clear whether three separate procedures were necessary to obtain all such benefits. Moreover, a residual risk of their overlapping is present. A defendant is not overly determined/inclined to have a plea-bargaining agreement concluded with the prosecutor, since the same result (a mitigated penalty) appears to be available with less effort directly by asking the judge to accept a confession to the act. Further, a procedure designed to grant legal effects to the passivity of a defendant (nolo contendere) brings a scarce profit, since no mitigating consequence whatsoever occurs here.

Apparently, the Romanian legislator has been seduced by the diversity of modes to optimize the criminal trial and yearns to taste them all. It would not be surprising if this pantagruelic feast ended with indigestion.

\section{BIBLIOGRAPHY}

\section{Literature}

1. Ashworth A. \& Redmayne M. The Criminal Process. New York: Oxford University Press, 2010.

2. Bodoroncea G. Acordul de recunoaștere a vinovăției [Plea Bargaining]. In: Codul de Procedură Penală. Comentariu pe articole [Criminal Procedure Code. Commentary on Articles]. $2^{\text {nd }}$ edition, Bucharest: C.H. Beck, 2017.

3. Ciopec F. Crime Control or Due Process? Which are the Tendencies in Romanian Criminal Justice. Journal of Eastern European Criminal Law, No. 1, 2017.

4. Ciopec F. The New Romanian Code of Criminal Procedure. Journal of Eastern European Criminal Law, No. 1, 2014.

5. Ghigheci C. Principiile procesului penal în noul Cod de procedură penală [Principles of Criminal Trial under the New Criminal Procedure Code]. Bucharest: Universul Juridic, 2014.

12 Manolescu M. I. Teme pentru o metodologie juridică privită ca disciplină autonomă [Topics for a legal methodology regarded as an autonomous discipline]. Bucharest: Fundația Regele Mihai I, 1946 , p. 52. 
6. Manolescu M. I. Teme pentru o metodologie juridică privită ca disciplină autonomă [Topics for a legal methodology regarded as an autonomous discipline]. Bucharest: Fundaţia Regele Mihai I, 1946.

7. Mateuț Gh. Procedură Penală. Partea generală [Criminal Procedure. General Part]. Bucharest: Universul Juridic, 2019.

8. Udroiu M. Procedură Penală. Partea generală [Criminal Procedure. General Part]. $6^{\text {th }}$ edition, Vol. I, Bucharest: C.H. Beck, 2019.

\section{Legislative acts}

1. Criminal Procedure Code (1968) entered into force on January 1, 1969.

2. Criminal Procedure Code (2010) entered into force on February 1, 2014.

\section{Legal practice}

1. Romanian Constitutional Court judgement No. 171 of 23 May 2001 published in Official Journal No. 387 of 16 July 2001.

\section{Other sources}

1. Romanian Superior Council of Magistracy. Reports on the State of Justice 2007-2018. 